\title{
Street Furniture as A Media Communication in Public Space
}

\author{
T Endahyani ${ }^{1}$, Y Sofiana ${ }^{2}$, B Kartono ${ }^{3}$ \\ ${ }^{1,2,3}$ Interior Design Department, Bina Indonesia University, Jakarta, Indonesia \\ ${ }^{1}$ tindahyani@binus.edu,
}

\begin{abstract}
The increasing of tourism in Jakarta currently requires public space that can support tourism facilities and also serve as an area of cultural conservation of old buildings. One of the supporting facilities of public space is street furniture. Street furniture located in Taman Fatahillah (Fatahillah park) area in Kota Tua (old town), Jakarta, has a role as a media to strengthen the concept of old town's identity area and become local cultural media communication that supports tourists attraction. However, the above street furniture is still less optimized as a media of local cultural communication. This study aims to strengthen the function and local identity of Taman Fatahillah through street furniture that support social and creative economy as well as supporting the tourism sector for local culture information. The methodology used is literature study, observation, interviews, and documentation on Taman Fatahillah. Some recommendations of street furniture design studies that are in accordance with the concept of the development of the old city's historical conservation area are generated from this research and are expected to be replicated for various locations in the historical, cultural and tourist areas of other cities in Indonesia which has a positive impact on wellbeing of local communities
\end{abstract}

Keywords: Street Furniture, Taman Fatahillah, Public Space

\section{INTRODUCTION}

Taman Fatahillah located in the old town of Jakarta is an open public space that has the potential to be able to revive the city atmosphere and increasing the economic movement in the old city of Jakarta. The name of Taman Fatahillah was only inaugurated in 1973 by the Local Government of DKI. This name was given to commemorate Fatahillah Commander as the founder of Jakarta. As the times change, this public space changes from time to time according to the dynamics of the city of Jakarta, which continues to grow rapidly and in line with the change of policy of DKI Jakarta.

The local government of DKI Jakarta gives a considerable influence on the utilization of public space function in Taman Fatahillah. As an element of urban space that reflects the identity of the city in the conservation area and the old city cultural heritage, the presence of street furniture facilities in the public space is no longer just a means that is devoid of philosophical and aesthetic values. Management of urban planning, historical aspects of building architecture and the presence of street furniture in an integrated public space can 
support the aesthetic values of the city and can function as a medium of social interaction culture of its consumer community.

\section{METHOD}

This research location is in Fatahillah square area in Jakarta city. The research was conducted from March to August 2018. The research method used was qualitative research with a series of activities as follows; (i) Literature study, sourced from scientific journals, reports, books, newspapers, magazines,electronic media and literature studies relating to research materials, (ii) Field survey, survey of street furniture in public spaces in Fatahillah square, Kota Tua, will be conducted directly to find problems in street furniture. Field survey data includes documentation of other visual images related to research objects and field notes. (iii) Case study, This research will use case study in Fatahillah square, Kota Tua as one of history conservation area in urban area. With case studies expected to better understand the situation. Conditions and problems of street furniture in a cultural conservation area that is also included as a tourist area in the old city. (iv) Interviews, interviews will be conducted to several resource persons to reveal more in the existing problems, especially in relation to the social, cultural and economic issues associated with this research. (v) Questionnaire, In this study will be conducted questionnaires to the speakers. In the early stages the resource person is asked to write down some answers for each question. In the next few stages, the resource persons are asked to choose the answer and re-fill the answers to each question. By writing answers to questions from the questionnaire is expected to open other aspects of street furniture from the point of view of the speakers.

\section{RESULT AND DISCUSSION}

\subsection{Taman Fatahillah as One of Public Space in Kota Tua}

In the master plan of Kota Tua Jakarta, one of the points that will be revitalized is Taman Fatahillah, its function as a place of mass performances. As part of the old town area, Taman Fatahillah (Fatahillah park) is the center of Kota Tua often used for community gatherings or special events such as bazaars, art festivals and food festivals that attract tourists. The problems faced by the Kota Tua area including the other areas of Taman Fatahillah are the creative and informal sector industries [1]. But the old city also has power in terms of human resources, history, culture and art (graphic design, music, culinary, crafts, traditional dance, batik, culinary and painting) and has great potential as one of the world's major tourist destinations. Thus there is the fact that the creative industries in the old town area especially in Taman Fatahillah are very potential to be developed as part of the development of local culture as well as become a valuable source of inspiration for this research in the future.

Taman Fatahillah with a capacity of 3000 - 5,000 people and can be used as a place of art music, folk performances and video mapping. But in its development, the old town needs to consider the environmentally-friendly pedestrian facilities that connect with other public areas so that the old town area is more attractive and more accessible to tourists [1]. Some suggestions from UNESCO to the Local Governments in Kota Tua include empowering and promoting creative industries, facilitating areas for street vendors, providing opportunities for developing the skills of art workers and developing infrastructure and services that can support the tourism sector, such as providing easy access to information as well as the needs of other facilities such as hotels, restaurants, including transportation, parking and pedestrian areas are 
safe and comfortable. In this case, street furniture as one of the pedestrian facilities, of course, is very likely developed as one of the complementary facilities in the old city that could potentially serve as part of strengthening the identity of local culture through the concept of design.

\subsection{Street Furniture in Public Space}

Public space location designed can be access by anyone. As part of social norms, everyone can interact in the public space unplanned. To be categorized to function optimally, public space or open space must be able to meet the aspects of ethics (ethics), functional (truth) and aesthetics or beauty (Jokomono, 2004 in [2]). The existence of street furniture in the area of public space today has become an important factor in strengthening the concept of the region. Street furniture is a "tool or street furniture" in the form of supporting elements of activities on the road or public space and is required for strengthening the character in the planning of a larger area (Permen PU no 6 2007). According to the Department of Public Works of the Directorate General of Highways, street furniture is a complementary or support facility for pedestrian paths adapted to the type of area placed along the road. While [3], argue that street furniture is a placement of elements,elements collectively, local character, in harmony with the environment and located in a road (landscape) area. The purpose of element placement is to provide comfort, safety, pleasure, circulation control and information for road users. In this study, street furniture is an element that has a local cultural identity and strengthens the concept of old town, placed collectively in the pedestrian area, in accordance with the type of area and the surrounding environment and is destined for the needs of pedestrians and tourists around the area of Taman Fatahillah.

Criteria on street furniture, according to [3], among others the application of materials that are resistant to weather, easy to maintain and repair, easy to obtain, safe for users. The need for street furniture is an effort to fulfill the functions of security and comfort (pedestrian road, traffic signs, shelters, fire hydrants, police substations, plant elements as shade and pedestrian paths), complementary functions (dustbins, mailboxes, seating, telephone, container, information) and aesthetic function (texture, color, shape). Preservation of World Heritage sites also involves the design of public spaces with particular attention to be given to function, scale, materials, lighting, street furniture, advertising, and plants [4]. Thus, the existence of this research is expected to realize street furniture as one of facilities and facilities in Taman Fatahillah become facilities other than functional, aesthetic, also able to display local culture that supported tourism program in Kota Tua. Here are some street furniture that will be focused in this research.

\subsection{Street Furniture as A Security, Comfort and Aesthetic Needs}

Street furniture also has a function in meeting the need for security, comfort and aesthetic needs. Street furniture that generally supports this function includes street lights, shelter shade, guardrail, seating, bins, container plant and information boards. Other functions from street furniture are as follows: (1) Street lighting aims to accommodate the safety of pedestrians and vehicles through appropriate lighting effects, among others, through the color of lights, distance and height differences [3], (2) Seats (bench), generally placed on the side of the road in the pedestrian area, especially in tourist areas, city parks, and shops. The road bench consists of a single bench and a group bench. Based on [3], the concept of bench planning takes into account aspects of function, shape, ergonomics, material, color, maintenance and 
high endurance. Based on [5], a good bench design can be uniquely designed from simple but sturdy materials, easily replicated with a dynamic organic shape (curved/twisted) with a firm color. (3) Dumpster, placed in large quantities at user activity locations in public areas that are easy to see and reach with easily recognizable shapes. Good waste dump criteria based on the [5] are functional as well as aesthetic elements and can improve the visual quality of the region and the placement in accordance with the context. (4) Plant container, according to [5], a good container in addition to functioning as a place of plants, also serves as a seat for users (for box plants). Plant containers should also provide a unique visual appearance of interest such as using a game of geometric shapes on the box of plants as well as with material combinations. Plant containers are specially designed to fit the concept of regional development. (5) Signage, a board that gives directions to road users regarding location, direction and destination information. Generally the information board is placed at the meeting point to facilitate road users to get information. Good signage according to [5], among others, has an informative map, packaged modern, good graphic design and informative, functioning to show the level, using good materials and weather resistance. From the data above shows that street furniture is placed not only as a basic functional element but has other functions in terms of fulfilling the need for security, comfort, information, complementary and aesthetic or visual elements are good.

\subsection{Street Furniture as A Medium for Local Culture Communication}

Cultural preservation has several values such as cultural, aesthetic, social, symbolic, educational and environmental [6]. Culture and communication are two interrelated things. Culture is part of communication behavior while communication contributes to the maintenance, development and preservation of culture. The effectiveness of interaction between cultures has dependence on intercultural communication which in this case can be activity of delivery and receipt of message in the form of symbol. "Culture is communication and communication is culture" [7]. The selection of good shape and design of street furniture will potentially have a role in supporting the reinforcement of local cultural identity through the visual information of local culture applied to street furniture's design concept.

As the result of study and discussion by considering aesthetic and functional values, the research shows that there is lack of integration between the current condition of street furniture at Taman Fatahillah to its historical surroundings. The integration of street furniture and historical values of architectural buildings and landscape have the potential to contribute in strengthening the identity concept of Kota Tua through the implementation of local cultural aspects to attract more tourists. According to design perspective, there is a need to improve the facilities of street furniture at Taman Fatahillah by considering the government standard criteria and regulations of comfort, aesthetics and cultural heritage condition.

Based on observations at Taman Fatahillah, this public space area is one of the interesting and meaningful destination for domestic and foreign tourists as a cultural and historical of Kota Tua (The Old City) public in Jakarta. However, there is a lack of connection between user activities and facilities that still need to consider the basic concept of regional regulation. This study focuses on the study of elements of street furniture in public space at Taman Fatahillah. As a public space and product service, Taman Fatahillah facilities serve as a media of communication that can be studied based on public space facility categories. The discussion of the object of research on street furniture in public space Taman Fatahillah are including: information board, garden chair, plant container, garden lights, wash bin, garden fountain and public toilet. 


\subsubsection{Information Boards (Signage)}

The road signage is a category of communication and information facilities. Its location is placed around the Taman Fatahillah which serves to facilitate road users to search for information The Information boards usually in the form of simple round poles with a light green direction, using metal materials, design aesthetically that can be developed according to the character of surroundings architectural buildings. The placement and installation of the pole is close to other street furniture such as container plants, benches, and bins, that significantly reducing the aesthetic visual aspect. In addition, there is lack of map landscape of Taman Fatahillah, which potentially could guide the visitors for a comprehensive environmental information (Figure 1).

\subsubsection{Garden Chair (Stool/Bench)}

Stools or benches are a leisure service facility. The existing design at Taman Fatahillah are in the form of a simple square box measuring about $35 \times 35 \times 45 \mathrm{~cm}$. Its produced by cement molding technique with the rock's color and character, functioned as seating facility, and also as a side barrier at Taman Fatahillah area.The seating area is provide with high resistance to suit to the outdoor conditions. Field work results show that there are only a few benches (bench) around Taman Fatahillah. Based on fieldwork observations, it shows that there is lack of seating area for groups of people, including for family, and women with children. Therefore, there is still need to fulfill the bench facility at Taman Fatahillah to fulfill the need of comfort, unique and artistic bench that support the character of the Historic building around Taman Fatahillah (Figure 2).

\subsubsection{Plant Container}

Plant containers are included in the category of art facilities. However, based on fieldwork, there are limited plants that can serve as a shade or shelter in street furniture public space area at Taman Fatahillah. In terms of design, plants container at Taman Fatahillah consists of two shapes, cup shapes as a container of plants and square shapes as a base made of white cement material. Visual appearance of plant container can be designed with variations of shape in accordance with the concept of street furniture design with wood and metal elements as materials substitution (Figure 3).

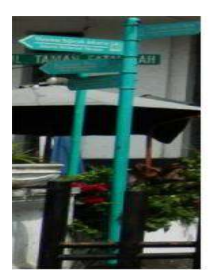

Figure 1. Signage. Plant Container (TE, 2017)

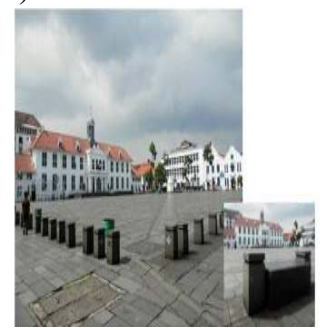

Figure 2. Bench. (TE, 2017)

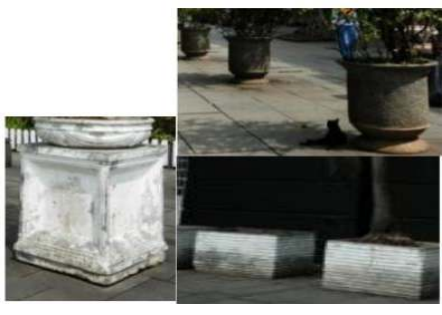

Figure 3. (TE, 2017) 


\subsubsection{Garden Lights or Street Lights}

Garden lights or street lights are included as a safety facilities. The garden lights at Taman Fatahillah are classic-style that combined with the latest LED light technology components. The garden lights are functioned as street lighting that accommodates the safety of pedestrians in the public space area and also has a visual artistic value. There are two types of garden lights at Taman Fatahillah that consisting of street lights that have 2 columns of branches and a single street lights, each adapting to the character of the building and the environment around the area (Figure 4).

\subsubsection{Waste Bin}

The waste bin is also included in the category of art facilities. There is still lack of good design concept for the bin facilities at Taman Fatahillah. Similarly, the placement of garbage container appears located in an in- appropriate location that relate to the user activity. Field observation results also show that the waste bin materials still produced by using the drum recycle materials that reduce the visual quality of public space at Taman Fatahillah. The waste bin need further design to create an integrated object to surrounding environment. The waste bins are placed in many locations scattered at Taman Fatahillah. Thus, it is necessary to present that the waste bin in several good criteria, such as function, good visual quality and have artistic value that can be adapted to local culture and surrounding environment (Figure $5)$.

\subsubsection{Garden Fountain}

Fatahillah Garden fountain is an art facility. The location is in the middle of the park. The shape of the fountain was the result of archaeological reconstruction in 1973 and derived from the function of a fountain ever made between 1850 and 1870. In the past, aside from being a garden fountain, the presence of this fountain also served as a place for people to search for the water during the reign of Batavia. This fountain still retains its original form as a reminder of the history of the fountain that once existed in Batavia's square (Figure 6).

\subsubsection{Public Toilets}

One of the important health and safety facilities is public toilets. The availability of permanent toilet facilities in public spaces of Taman Fatahillah is still limited. The existing design concept is lack of attention to the hygiene and ergonomic aspect The addition of portable toilets is provide on a temporary period. However, a special design on public portable toilets can be a solution for users in the area of public space at Taman Fatahillah (Figure 7). Therefore, there are lack of integrated design concept for street furniture at Taman Fatahillah. Each category of street furniture need to be further develop to support the local identity in Kota Tua area, especially at Taman Fatahillah. In this research, street furniture has the potential role as a media in communicating local culture by further develop the design concept that applied the unique local culture and engaged local society. 

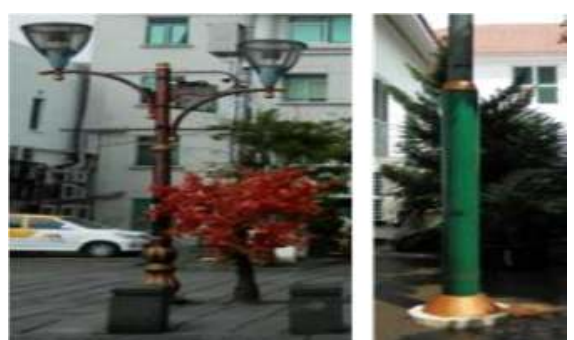

Figure 4. Street lights (TE, 2017)

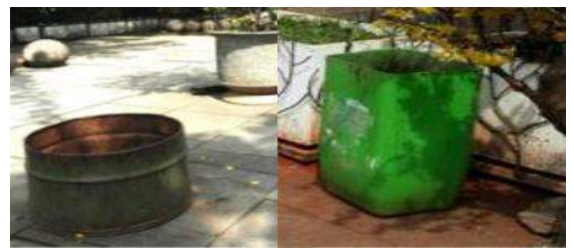

Figure 5. Waste Bin. (TE, 2017)

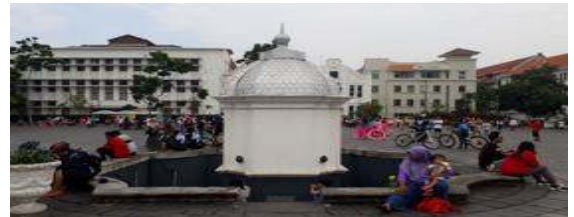

Figure 6. Garden Fountain (BK, 2018)

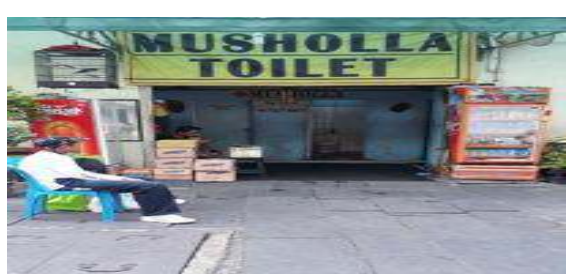

Figure 7. Public Toilet. (BK, 2018)

\section{CONCLUSION}

In accordance to the environment landscape, the existence of Taman Fatahillah is in the aesthetic function of street furniture. However, asa public space area,Taman Fatahillah also play the image of a city by conveying cultural communication through communication media that can interact directly with the society. The study of functional and aesthetic value of street furniture facilities in public space at Taman Fatahillah requires design that adapts to the environment and landscape of the building's character and surrounding local environment. The potential of good design can contribute to strengthen the concept of the character of the Historic Kota Tua area and can act as a medium of cultural communication to attract more tourists. 


\section{ACKNOWLEDGMENTS}

This research was supported in part by Bina Nusantara University Grant 2018 for School of Design, Interior Design Department.

\section{REFERENCES}

[1] UNESCO, Analytical study of Kota Tua. Jakarta: UNESCO, 2014.

[2] M. Baskara, "Kajian Ruang Terbuka Kawasan Pedestrian Kota Tua Jakarta," Medha Baskara Blog, 2012. [Online]. Available: http://medha.lecture.ub.ac.id/2012/02/kajian-ruang-terbuka-kawasan-pelestarian-kotatua-jakarta/. [Accessed: 14-Nov-2018].

[3] W. Harris and T. N. Dines, Time Saver Standarts for Landscape Architecture, 1st ed. New York: McGraw Hill Publishing Company, 1988.

[4] UNESCO, Vienna Memorandum and Decision 29 CO M 5D. Vienna: US: United Nations Educational, Scientific and Cultural Organization, 2005.

[5] C. karya Dirjen, Panduan Kualitas Visual Infrastruktur Bidang Cipta Karya. Jakarta: Kementrian Pekerjaan Umum dan Perumahan Rakyat, 2015.

[6] UCLG, Revitalizing Cultural Heritage: A comprehensive urban plan to revitalize Kota Tua in Jakarta. Jakarta, 2017.

[7] E. T. Hall, The Silent Language. New York: Doubleday, 1990. 